\title{
Following the requirements of Breast Cancer Centre-bettering outcomes of the treatment of the patients with a breast cancer
}

\section{Rak piersi - lepsze wyniki leczenia w ośrodku certyfikowanym}

\author{
Piotr Kędzierawski1,2, Paweł Macek¹,3, Stanisław Góźdź1,3 \\ ${ }^{1}$ Institute of Health Sciences, Collegium Medicum, Jan Kochanowski University, Kielce, Poland \\ Head of the Institute: Edyta Suliga \\ ${ }^{2}$ Breast Cancer Unit, Holycross Cancer Centre, Kielce, Poland \\ Head of the Unit: Piotr Kędzierawski \\ ${ }^{3}$ Epidemiology and Cancer Control Department, Holycross Cancer Centre, Kielce, Poland \\ Head of the Department: Paweł Macek
}

Key words: breast cancer, combined treatment, coordinated treatment.

Słowa kluczowe: rak piersi, leczenie skojarzone, koordynacja leczenia.

\begin{abstract}
Introduction: On 20 April 2015 the Breast Cancer Unit of Holycross Cancer Centre (HCC) in Kielce was granted with the certificate of the Senologic International Society (SIS), confirming the completion of quality criteria in diagnostics and therapy of patients with breast cancer (BC). In 2014 HCC strove to diagnose and treat patients with breast cancer following the commendations of the SIS.

Aim of the research: In this paper we provide the actualised outcomes of treatment after a 5-year observation.

Material and methods: In 2014 a total of 409 women were qualified to radical treatment of invasive cancer in Holycross Cancer Centre. The median time of observation was 60 months. The probability of disease-free survival and overall survival was estimated by the Kaplan-Meier method.

Results: Five-year disease-free survival (DFS) and overall survival (OS) for an entire group was 94\% and 90\%, respectively. DFS for women from pre-screening, screening, and post-screening age groups were $90 \%, 93 \%$, and $89 \%$ and OS $89 \%, 90 \%$, and $79 \%$, respectively; DFS in patients with stage I, II, III, and IV was $98 \%, 95 \%, 76 \%$, and $20 \%$, respectively and OS $97 \%$, $91 \%, 70 \%$, and $20 \%$, respectively.

Conclusions: We believe that proper coordination and cooperation between specialists who are engaged in the process of diagnostics and treatment of women with breast cancer is an important factor leading to improved outcomes of treatment.
\end{abstract}

\section{Streszczenie}

Wprowadzenie: 20 kwietnia 2015 r. zespół do spraw diagnostyki i leczenia raka piersi w Świętokrzyskim Centrum Onkologii w Kielcach otrzymał certyfikat Międzynarodowego Towarzystwa Senologicznego (SIS) potwierdzający spełnienie międzynarodowych kryteriów diagnostyki i leczenia chorych na raka piersi. W 2014 r. chore były diagnozowane i leczone według zaleceń SIS.

Cel pracy: $\mathrm{W}$ artykule przedstawiono aktualne wyniki leczenia chorych po 5 latach obserwacji.

Materiał i metody: Analizie poddano 409 chorych na inwazyjnego raka piersi leczonych radykalnie w 2014 r. w Świętokrzyskim Centrum Onkologii. Średni czas obserwacji wyniósł 60 miesięcy. Prawdopodobieństwo 5-letniego przeżycia bezobjawowego i całkowitego oszacowano metodą Kaplana-Meiera.

Wyniki: Prawdopodobieństwo 5-letniego czasu wolnego od choroby (DFS) oraz 5-letniego całkowitego czasu przeżycia (OS) dla całej grupy wyniosło odpowiednio 94\% i 90\%. Pięcioletni DFS u chorych w wieku 0-49, 50-69 i ponad 70 lat wyniósł 90\%, 93\% i 89\%, a pięcioletni OS w tych grupach odpowiednio 89\%, 90\% i 79\%. U chorych w poszczególnych stopniach zaawansowania klinicznego raka (I, II, III, IV) 5-letnie wskaźniki DFS i OS wyniosły odpowiednio 98\%, 95\%, 76\%, 20\% i $97 \%, 91 \%, 70 \%, 20 \%$.

Wnioski: Wierzymy, że właściwa koordynacja i współpraca między specjalistami zaangażowanymi w proces diagnostyki oraz leczenia chorych na raka piersi jest ważnym czynnikiem i przyczynia się do poprawy wyników leczenia. 


\section{Introduction}

On 20 April 2015 the Breast Cancer Unit of Holycross Cancer Centre (HCC) in Kielce was granted the certificate of the Senologic International Society (SIS), confirming the completion of quality criteria in the diagnostics and therapy of patients with breast cancer (BC). The preparation to the reception of accreditation had lasted since 2012. In 2014 HCC strove to diagnose and treat patients with breast cancer following the commendations of the SIS and other international boards [1]. We focused on the quality of diagnostics and the time between the diagnosis and the commencement of oncological treatment as well as the treatment time. Every patient qualified for the treat-

Table 1. Clinical characteristics of the patients

\begin{tabular}{|c|c|}
\hline Factor & Results \\
\hline \multicolumn{2}{|l|}{ Age } \\
\hline Min. & 20 \\
\hline Max. & 89 \\
\hline Mean & 60.48 \\
\hline Pre-screening group, $n(\%)$ & $66(16)$ \\
\hline Screening group, $n(\%)$ & $274(67)$ \\
\hline Post-screening group, $n$ (\%) & $69(17)$ \\
\hline \multicolumn{2}{|l|}{ Stage: } \\
\hline I & $147(36)$ \\
\hline II & $175(43)$ \\
\hline III & $82(20)$ \\
\hline IV & $5(1)$ \\
\hline Luminal A, $n(\%)$ & $207(51)$ \\
\hline Luminal B, $n(\%)$ & $70(17)$ \\
\hline Luminal B HER2-positive, $n$ (\%) & $62(15)$ \\
\hline Triple-negative, $n$ (\%) & $42(10)$ \\
\hline Non-luminal, $n(\%)$ & $24(6)$ \\
\hline Other, $n(\%)$ & $4(1)$ \\
\hline Breast-conserving treatment, $n(\%)$ & $196(48)$ \\
\hline Radical mastectomy, $n$ (\%) & $178(43)$ \\
\hline Simple mastectomy, $n$ (\%) & $22(5)$ \\
\hline Subcutaneous mastectomy, $n(\%)$ & $13(3)$ \\
\hline \multicolumn{2}{|l|}{ Sentinel lymph node biopsy, $n$ (\%): } \\
\hline Yes & $212(52)$ \\
\hline No & $197(48)$ \\
\hline Chemotherapy, $n$ (\%) & $162(40)$ \\
\hline Hormonotherapy, $n$ (\%) & $337(82)$ \\
\hline AntiHER2 therapy, $n(\%)$ & $68(17)$ \\
\hline Radiotherapy, $n$ (\%) & 315 (77) \\
\hline
\end{tabular}

ment was discussed by the team of specialists and referred to a medical case meeting that was responsible for the provision of treatment whose specificity was adjusted to the biological profile of the cancer.

\section{Aim of the research}

In the paper we provide the actualised outcomes of the treatment after a 5-year observation.

\section{Material and methods}

In 2014 a total of 441 women were qualified to the radical treatment, including 409 patients with invasive cancers and 32 with preinvasive cancer who were excluded from an analysis. The mean age was 60 years, with the youngest aged 20 and the oldest aged 89 years. Two hundred and seventy-four patients were at the age of screening, in post-screening and pre-screening groups 69 and 66 years, respectively. In women with invasive cancers qualified to the surgical treatment 147 were diagnosed with stage I, 175 with stage II, 82 with stage III, and five with stage IV of the cancer. Luminal A cancer was recognised in 207 patients and luminal B in 132, including 62 with HER2-positive cancer, triple-negative (TN) in 42 , and non-luminal (NL) in 24. Two cases involved adenoid cystic carcinoma, and in 3 cases angiosarcoma was recognised. The treatment was conducted following the recommendations of the Polish Society of Clinical Oncology. The majority of patients (196 patients) were treated with breast-conserving therapy (BCS), radical mastectomy was performed in 178 patients, simple mastectomy in 22, and subcutaneous mastectomy with an immediate reconstruction with prosthesis in 13 patients. The procedure of sentinel lymph node biopsy (SLNB) was performed in 212 and axillary dissection in 197 patients. Chemotherapy was provided to 162 patients, including 47 prior to a surgery (in seven with luminal A cancer, 22 in luminal B, 10 with $\mathrm{TN}$, and eight with non-luminal cancer). The most commonly used regimen of chemotherapy was $4 \times$ doxorubicin and cyclophosphamide $(4 \times \mathrm{AC})$ and $12 \times$ paclitaxel (P). Prior to systemic therapy every patient was consulted by a cardiologist. Hormonotherapy was provided to 337 women, including three prior to surgery. Anti-HER2 treatment was provided to 72 patients. Irradiation was conducted in 315 patients (Table 1). If adjuvant systemic treatment and radiotherapy were used, irradiation was applied after the completion of chemotherapy. Combining the use of trastuzumab and radiotherapy was allowed. All patients were observed after the treatment in Holycross Cancer Centre. Posttreatment rehabilitation during a concurrent observation was conducted. Patients received psychological support and genetic consultations. In patients with BRCA mutations proper procedures were implemented by the specialists of clinical genetics. The median time of observation was 60 months. 
The probability of disease-free survival and overall survival was estimated by the Kaplan-Meier method.

\section{Results}

Five-year disease-free survival (DFS) and overall survival (OS) for the entire group was $94 \%$ and $90 \%$,

\section{A}

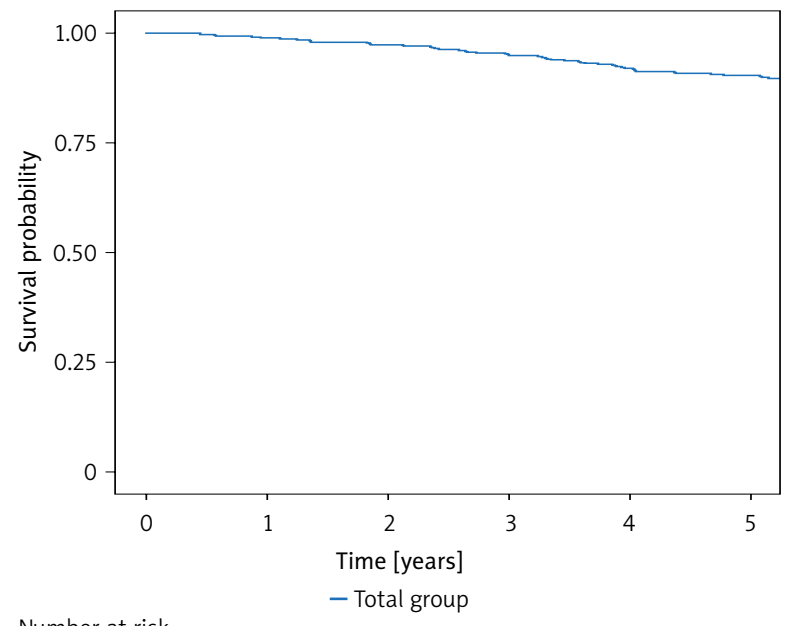

Number at risk

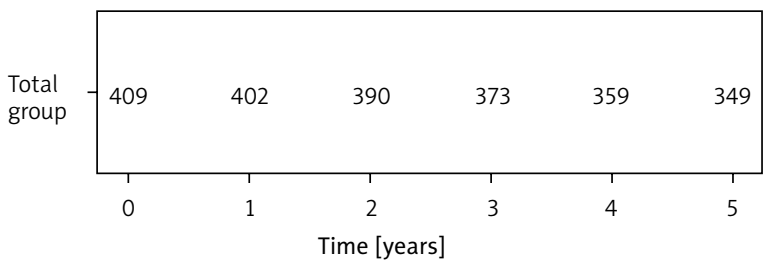

C

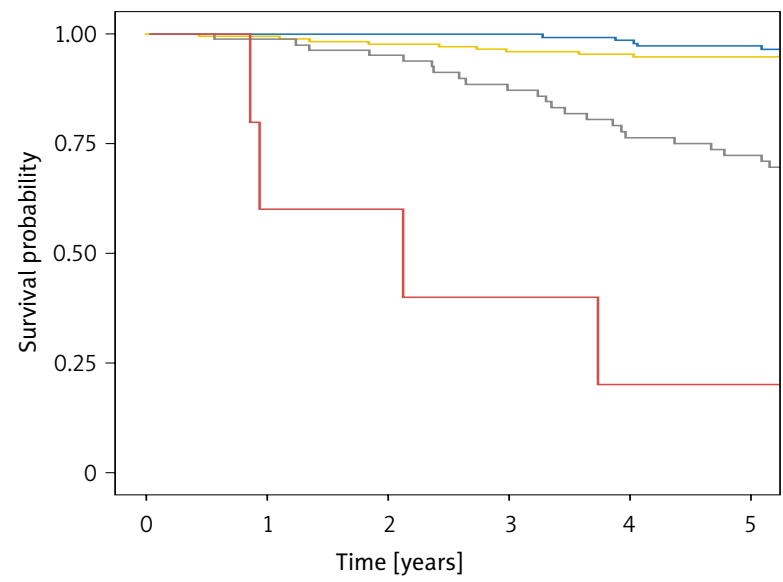

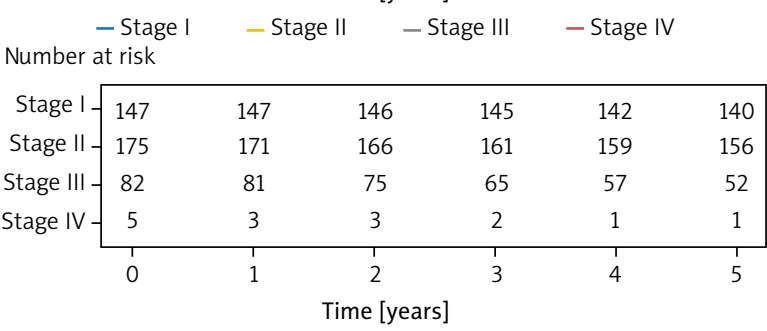

respectively. Five-year DFS for women from pre-screening age, screening age, and post-screening age groups were $90 \%, 93 \%$, and $89 \%$ and 5 -year OS $89 \%$, 90\%, and 79\%, respectively; 5-year DFS in patients with I, II, III, and IV stage was 98\%, 95\%, 76\%, and $20 \%$, respectively and 5-year OS 97\%, 91\%, 70\%, 20\%, respectively (Figures 1, 2).

B

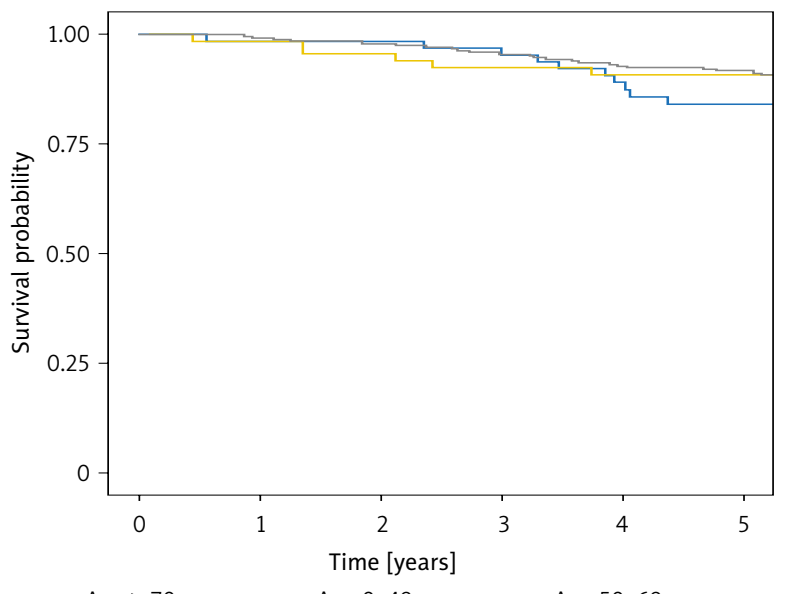

- Age $\geq 70$ years - Age $0-49$ years - Age $50-69$ years Number at risk

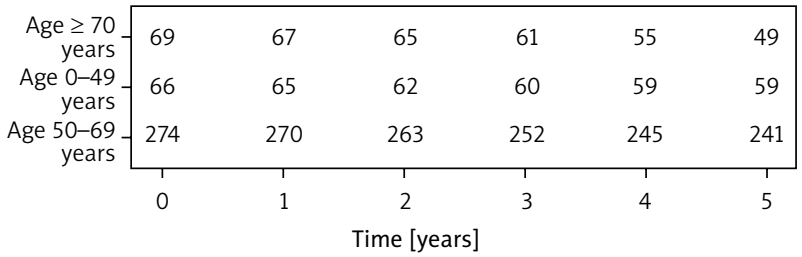

Figure 1. Disease-free survival: A - in the whole group, $\mathbf{B}$ - by age group, $\mathbf{C}$ - by stage of cancer 


\section{Discussion}

The creation of a team for the diagnostics and treatment of patients with breast cancer should contribute to improving of the outcomes of the treatment. The analysis of our own results represents a significant element of clinical work. Following the recommenda-

\section{A}

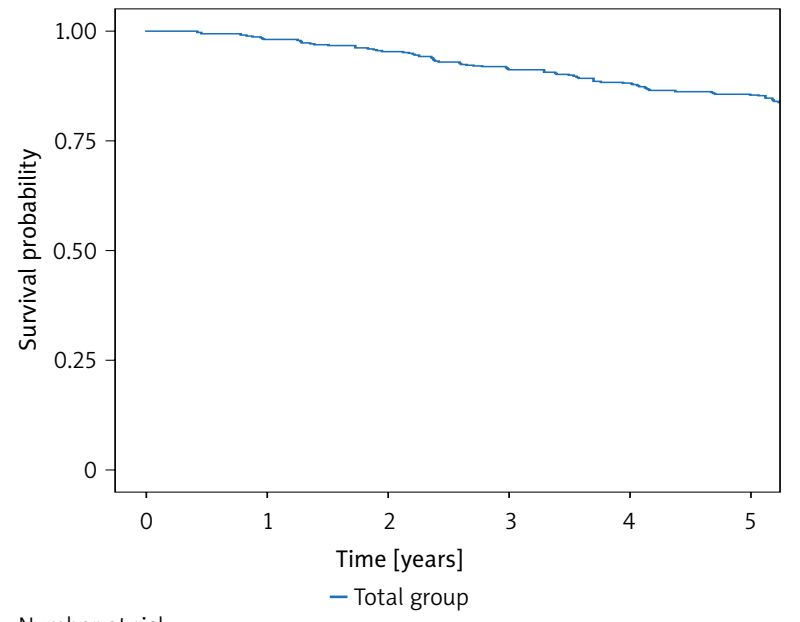

Number at risk

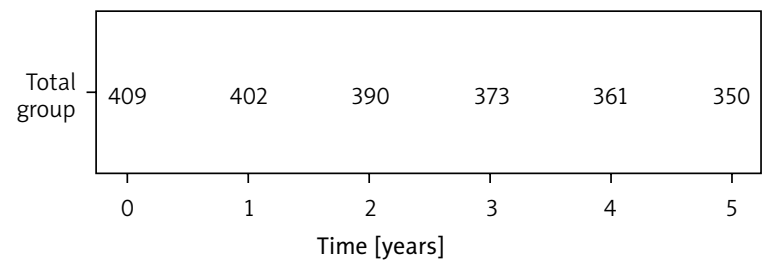

C

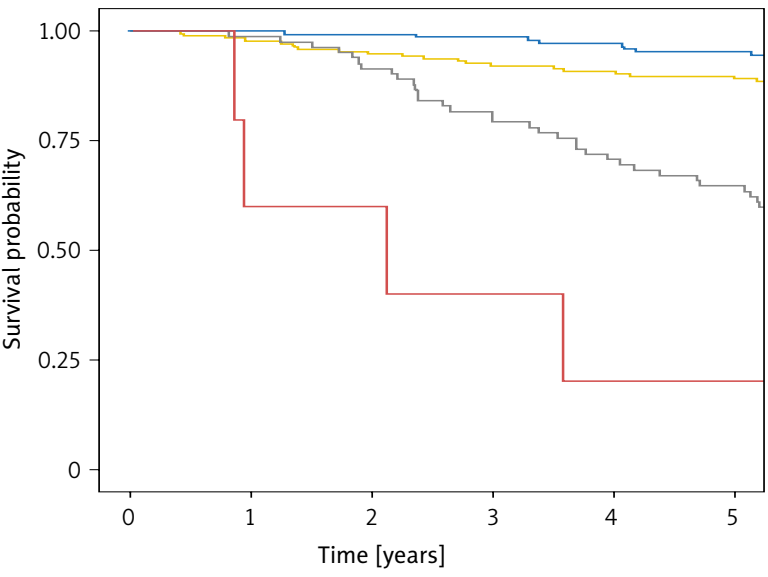

- Stage I - Stage II - Stage III - Stage IV

Number at risk

\begin{tabular}{|c|c|c|c|c|c|c|}
\hline Stage I & 147 & 147 & 146 & 145 & 143 & 140 \\
\hline Stage II - & 175 & 171 & 166 & 161 & 159 & 156 \\
\hline Stage III - & 82 & 81 & 75 & 65 & 58 & 53 \\
\hline Stage IV & 5 & 3 & 3 & 2 & 1 & 1 \\
\hline & 1 & 1 & 2 & 3 & 4 & $\begin{array}{l}1 \\
5\end{array}$ \\
\hline \multicolumn{7}{|c|}{ Time [years] } \\
\hline
\end{tabular}

tions is a crucial element, and the period of treatment and its continuity are highly substantial. The indicators of the quality of the oncological treatment are DFS and OS. The presented outcomes of treatment do not diverge from European and world results. According to the Cancer Registry in Poland the 5-year OS in patients with breast cancer between 2003 and 2005

B

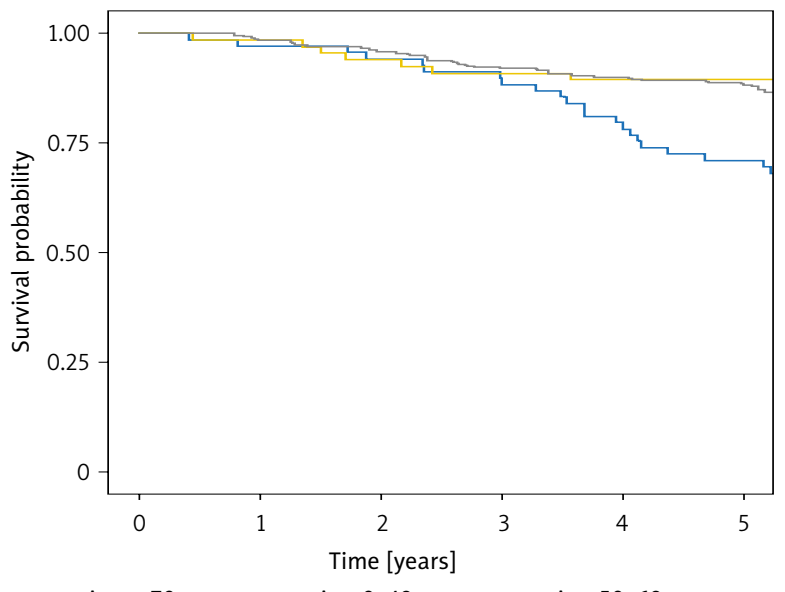

- Age $\geq 70$ years - Age $0-49$ years - Age 50-69 years Number at risk

\begin{tabular}{|c|c|c|c|c|c|c|}
\hline $\begin{array}{r}\text { Age } \geq 70 \\
\text { years }\end{array}$ & 69 & 67 & 65 & 61 & 55 & 49 \\
\hline Age $0-49$ & 66 & 65 & 62 & 60 & 59 & 59 \\
\hline \multirow{3}{*}{$\begin{array}{r}\text { Age } 50-69 \\
\text { years }\end{array}$} & 274 & 270 & 263 & 252 & 247 & 242 \\
\hline & 0 & 1 & 2 & 3 & 4 & 5 \\
\hline & \multicolumn{6}{|c|}{ Time [years] } \\
\hline
\end{tabular}

Figure 2. Overall survival: A - in the whole group, $\mathbf{B}$ - by age group, $\mathbf{C}$ - by stage of cancer 
was $77 \%$ [2]. In the publication Nowotwory Journal of Oncology from 2018 the results of the treatment of patients with breast cancer in the Holycross Voivodship were presented. These results significantly differ from previously and currently presented results [3-5]. In the analysed group the results are much better.

The treatment scheme in patients since the year 2014 has changed [6]. For luminal A breast cancer patients in stage I and II the treatment is based on surgery and most commonly hormonotherapy. In women undergoing BCS radiotherapy is implemented. This particular scheme is prevailing. Luminal B patients are presently treated with upfront chemotherapy and anti-HER2 therapy. In cases with overexpression of HER2 receptor anti-HER therapy is accompanied with systemic treatment. Following surgery, immunotherapy and radiotherapy are provided, if indicated. The treatment in patients with TN, NL cancers starts with systemic therapy. In patients with the diameter of the primary tumour less than $10 \mathrm{~mm}$ surgery should be considered. TN and NL patients have the highest probability of complete pathological regression after systemic treatment, which is a good prognostic factor, and which in many women allows breast-conserving therapy to be performed. In the analysed group, in patients with TN and NL cancers a neoadjuvant treatment was not conducted in the majority of cases. In HER2-positive patients, because of the early stage of the cancer or cardiological counterindications, the therapy with trastuzumab was not provided. Subcutaneous mastectomy with an immediate reconstruction with the prothesis was the novel method used for our patients in different biological types of cancers. What is important in our analysis is that the best outcomes were achieved in women between 50 and 69 years of age (screening group), which confirms that a cancer recognised early can be most effectively treated.

\section{Conclusions}

The presented outcomes show that the appropriate organisation and coordination of treatment in BC patients allows for obtaining significantly good treatment results despite some differences in a therapeutic attitude. We should furthermore analyse clinical outcomes, particularly in cases of failures. In the following observations treatment outcomes should be compared, particularly in patients in LB HER2-positive, TN, and NL cancers, because the therapeutical attitude has changed compared to that of 2014, and it primarily relies on preoperative systemic treatment in the vast majority of patients. We believe that proper coordination and cooperation between the specialists who are engaged in the process of diagnostics and treatment of women with breast cancer is an important factor leading to improved outcomes of treatment.

\section{Conflict of interest}

The authors declare no conflict of interest.

\section{References}

1. Wilson ARM, Marotti L, Bianchi S, Biganzoli L, Claassen S, Decker T, Frigerio A, Goldhirsch A, Gustafsson EG, Mansel RE, Orecchia R, Ponti A, Poortmans P, Regitnig P, Rosselli Del Turco M, Rutgers EJT, van Asperen C, Wells CA, Wengström Y, Cataliotti L, EUSOMA (European Society of Breast Cancer Specialists). The requirements of a specialist Breast Centre. Eur J Cancer 2013; 49: 3579-3587.

2. National Cancer Registry - National Institute of Oncology.

3. Kędzierawski P, Ciepiela I, Florek A, Bocian A, Macek P, Howorus M, Góźdź S. Long-term results of combined treatment patients with early breast cancer after conserving therapy. Medical Studies 2016; 32: 164-169.

4. Kędzierawski P, Bocian A, Ciepiela I, Kołacińska A, Macek P, Góźdź S. Treatment outcomes of 213 breast cancer patients after sentinel lymph node biopsy - single center experience. Arch Med Sci Civil Dis 2017; 2: e130-e134.

5. Bielska-Lasota M, Krzyżak M, Kwiatkowska K, Bogusz J, Maślach D, Wysocki MJ. Differences in treatment outcomes in selected cancers in Poland compared to other European countries in 2005-2009, based on CONCORD 2 study. Nowotwory J Oncol 2012; 66: 202-211.

6. Cardoso F, Kyriakides S, Ohno S, Penault-Llorca P, Poortmans P, Rubio IT, Zackrisson S, Senkus E, ESMO Guidelines Committee. Early breast cancer: ESMO Clinical Practice Guidelines for diagnosis, treatment and follow-up. Ann Oncol 2019; 30: 1194-1220.

\section{Address for correspondence:}

\section{Piotr Kędzierawski PhD}

Institute of Health Sciences

Collegium Medicum

Breast Cancer Unit

Jan Kochanowski University

Holycross Cancer Centre

Kielce, Poland

Phone: +48 609211933

E-mail: piotrkedzierawski@wp.pl 